\title{
„ZAUFAJ DOBRYM RADOM”. UWARUNKOWANIA I PRZESŁANKI ROZWOJU RAD DZIELNIC NA PRZYKŁADZIE GDAŃSKA
}

\author{
“TRUST GOOD ADVICE”. CONDITIONS AND PREREQUISITES \\ FOR THE DEVELOPMENT OF DISTRICT COUNCILS. \\ A CASE STUDY OF GDANSK
}

DOI: $10.25167 / \mathrm{sm} 2017.025 .03 \quad$ s. $59-75$

\begin{abstract}
ABSTRAKT: Na przestrzeni ostatnich kilku lat w Polsce obserwuje się rosnący udział mieszkańców miast $\mathrm{w}$ działaniach na rzecz najbliższego otoczenia. Jednym z przejawów tego zjawiska jest powstawanie i funkcjonowanie rad dzielnic i osiedli. Sytuacja ta dotyczy również Gdańska, gdzie do roku 2010 istniało ich zaledwie kilka, natomiast w 2015 r. wybrano rady aż w 29 z 34 dzielnic. Celem artykułu jest diagnoza uwarunkowań aktywności oddolnej gdańszczan i gdańszczanek w ramach tych wyborów oraz zbadanie jej powiązań z innymi formami zaangażowania obywatelskiego. W artykule przedstawiono również motywy inicjowania rad w dzielnicach oraz sposoby ich funkcjonowania, zwłaszcza w kontekście ograniczonych kompetencji najniższego poziomu demokracji samorządowej. Zastosowane metody objęły przegląd dokumentów dotyczących dzielnic oraz analizę statystyczną wyników wyborów do jednostek pomocniczych w Gdańsku, także w zestawieniu z charakterystykami społeczno-ekonomicznymi poszczególnych dzielnic. W wytypowanych na tej podstawie jednostkach przeprowadzono dodatkowo indywidualne wywiady z przedstawicielami rad dzielnic.
\end{abstract}

SŁOWA KLUCZOWE: rady dzielnic, Gdańsk, demokracja lokalna, frekwencja wyborcza

ABSTRACT: Within the past few years in Polish cities there has been a rise in residents' participation in decision-making at the neighbourhood level. One of its symptoms is the creation and functioning of auxiliary units. Such is the situation in Gdansk, where before 2010 there existed only a few of them, while in 2015 district councils were elected in 29 out of 34 units. The aim of the paper is to diagnose the conditions of bottom-up activity of inhabitants of Gdansk in the elections to the district councils as well as to investigate their associations with other forms of civic engagement. The paper also presents motivations for initiation of district councils and the way they operate in, especially in consideration of their limited competence. The applied methods include a review of legal documents and a statistical analysis of the election results, including socio-economic characteristics in specific districts. Additionally, individual interviews with representatives of district councils were conducted to complement the picture.

KEY WORDS: district councils, Gdansk, neighbourhood, urban democracy, voter turnout

* Uniwersytet Gdański, Katedra Geografii Ekonomicznej, ul. Bażyńskiego 4, 80-309 Gdańsk, e-mail: jan. frankowski@ug.edu.pl,geomg@ug.edu.pl 


\section{Wprowadzenie}

Już starożytni Grecy twierdzili, że zbyt dużym miastem trudno zarządzać. Wraz ze wzrostem liczby mieszkańców rośnie skala i złożoność ich potrzeb, mnożą się problemy wynikające z konfliktów interesów, szybują w górę koszty utrzymania. Jednak postulowane przez Platona czy Arystotelesa ograniczanie wielkości miasta do optymalnego rozmiaru w dzisiejszych realiach jest niemożliwe. Pewną namiastką systemu zapewniającego bezpośrednie uczestnictwo mieszkańców ośrodka miejskiego w procesach decyzyjnych jest tworzenie jednostek pomocniczych na poziomie dzielnicy lub osiedla. Celem niniejszego artykułu jest przedstawienie warunków i sposobów funkcjonowania rad dzielnic w Polsce oraz czynników wspomagających ich efektywny rozwój. Analizę przeprowadzono na podstawie studium przypadku Gdańska jako miasta, w którym wzrasta zarówno liczba rad dzielnic, jak i frekwencja w wyborach ich przedstawicieli. Przyczyny tej dość nagłej popularności zapewne po części można upatrywać w ogólnoświatowej tendencji do umacniania się demokracji miejskiej.

Ekspansja ruchów miejskich czy popularyzacja budżetów obywatelskich oraz innych narzędzi partycypacji społecznej na szczeblu lokalnym wskazują na renesans lokalizmu i wzrost oddolnego zaangażowania szeroko pojętych mieszczan. Mamy obecnie do czynienia wręcz z globalnym „buntem miast”, w którym nawołuje się do odzyskiwania wspólnego prawa mieszkańców nie tylko do miejskich zasobów, ale i do zmiany przekładającej się na poprawę jakości życia w mieście (Harvey 2012). Wzrost zainteresowania współuczestnictwem w miejskim zarządzaniu ma szczególne znaczenie w Europie Środkowo-Wschodniej, gdzie po zakończeniu drugiej wojny światowej przez niemal półwiecze nie obowiązywały standardy demokracji, a systemowa ideologia skutecznie blokowała poczucie odpowiedzialności za wspólną przestrzeń. W okresie ostatnich 25 lat obywatelskość odradza się, lecz z wyraźnym oporem. W krajach postsocjalistycznych nadal bowiem pokutują wzorce z drugiej połowy XX w., gdy większość decyzji dotyczących funkcjonowania miast podejmowano na szczeblu centralnym, dlatego wdrażanie nowych standardów, choćby w zakresie partycypacji społecznej, wciąż nastręcza znacznych trudności. Pewien wpływ na przyspieszenie tych procesów w regionie przypisuje się najnowszym rozszerzeniom Unii Europejskiej (Fischer, Pleines 2014). Ma to związek m.in. z obowiązującą w państwach UE zasadą subsydiarności, zgodnie z którą kompetencje delegowane są na możliwie najniższy szczebel władzy.

Polskie doświadczenia w tej mierze nie stanowią odstępstwa od reguły. Rady dzielnic jako jednostki pomocnicze gminy zostały usankcjonowane ustawą o samorządzie gminnym z 1990 r., jednak ich dynamiczny rozwój rozpoczął się około dekady później. Stały się tym samym interesującym obiektem badawczym, przez co przybywa opracowań teoretycznych i empirycznych dotyczących poszczególnych miast. Do tej drugiej kategorii należą m.in. publikacje na temat funkcjonowania rad dzielnic w Poznaniu i Kaliszu (Matczak 2006), Krakowie (Jaśkowiec 2012), Łodzi (Kalisiak-Mędelska 2012) i aglomeracji śląskiej (Piechota 2013). W Gdańsku takie badania jak dotąd przeprowadzono raz (Raport z realizacji projektu... 2009), jednak dotyczą one okresu, gdy 
w mieście funkcjonowało zaledwie 13 rad dzielnic i osiedli, tymczasem w ostatnim pięcioleciu liczba ta wzrosła do 34, zaś przeprowadzone wiosną 2015 r. wybory dostarczyły nowego materiału badawczego. Co więcej, to właśnie wśród rad dzielnic zdążyła wyrosnać w ostatniej kadencji „oddolna” konkurencja dla obecnej władzy w Gdańsku, którą stanowi Gdańsk Obywatelski - ugrupowanie identyfikujące się z ruchami miejskimi, zdobywającymi coraz większe poparcie.

W artykule zastosowano mieszaną, dwustopniową strategię badawczą. W pierwszym, ilościowym etapie porównano aktywność obywatelską w 34 dzielnicach Gdańska, agregując oraz poddając analizie dane surowe pochodzące z Urzędu Miasta (wybory do rad dzielnic) oraz Państwowej Komisji Wyborczej (wybory ogólnomiejskie). Następnie uzyskane w tym przekroju zmienne zostały skorelowane z cechami społeczno-ekonomicznymi charakteryzującymi dzielnicę. Przeprowadzona analiza ilościowa posłużyła jako punkt wyjścia do sformułowania typologii postaw obywatelskich mieszkańców ze względu na dominujące w dzielnicy zasoby kapitału społecznego (zmierzone frekwencją wyborczą w 2014 r. w wyborach samorządowych i 2015 r. w ogólnomiejskich wyborach do rad dzielnic). Dwa skrajne przypadki, jeżeli chodzi o wysokość frekwencji w wyborach do rad dzielnic, zostały zbadane bardziej szczegółowo na podstawie przeglądu materiałów źródłowych, analizy statystycznej i pogłębionych wywiadów z radnymi przeprowadzonych w trakcie dyżurów obywatelskich. W trakcie prowadzenia badań autorzy uczestniczyli również w dwóch warsztatach na temat przyszłości rad dzielnic, organizowanych w Gdańsku przez trójmiejską świetlicę Krytyki Politycznej oraz Instytut Metropolitalny w pierwszym kwartale $2015 \mathrm{r}$.

W następujących częściach artykułu omówione są kwestie teoretyczne dotyczące ustanawiania i rozwoju rad jednostek pomocniczych w Polsce oraz charakterystyka tych procesów w Gdańsku. W dalszej kolejności przedstawiono wspomnianą wyżej typologię i studia przypadków dzielnic wykazujących najbardziej typowe lub nietypowe wzory.

\section{Aktywność oddolna na poziomie dzielnic w Polsce}

Pomimo wspomnianych we wprowadzeniu opóźnień w uruchamianiu idei subsydiarności na gruncie polskich miast znaczenie rad dzielnic rośnie. Rozwój tego najniższego szczebla samorządu terytorialnego jest istotny nie tylko z uwagi na efektywność organizacyjną, wynikającą z lepszego rozpoznania potrzeb lokalnych społeczności, ale także ze względu na wzmacnianie tożsamości mieszkańców oraz ich poczucia podmiotowości (Filar, Kubicki 2012). Zaangażowanie w sprawy najbliższego otoczenia wymaga dostępności odpowiednich narzędzi. Ekspansji rad dzielnic z pewnością sprzyja zatem coraz większa popularność instrumentów partycypacji społecznej, takich jak warsztaty charette czy budżet partycypacyjny, angażujących mieszkańców na poziomie mikrolokalnym, nawet jeśli nie wszystkie okazują się równie skuteczne (Basaj 2013).

Występuje jednak szereg problemów, z jakimi borykają się jednostki pomocnicze. Przede wszystkim ich kompetencje są niewystarczające w stosunku do oczekiwań 
mieszkańców, w rezultacie czego zainteresowanie działalnością rad dzielnic utrzymuje się na dość niskim poziomie. Efekt ten nazywany jest błędnym kołem marginalizacji (Swianiewicz, Lackowska, Krukowska, Kurniewicz 2013). Przekonanie o niewielkiej sprawczości radnych dzielnicowych przekłada się na słabą frekwencję w wyborach do rad jednostek pomocniczych, ta zaś utwierdza władze samorządowe w przekonaniu, iż nie ma potrzeby zwiększania ich uprawnień ani środków budżetowych. Z kolei we wspomnianym raporcie dotyczącym Gdańska (Raport z realizacji projektu... 2009) wskazuje się też na niską świadomość społeczną na temat jednostek pomocniczych oraz na ułomność podziału administracyjnego miasta. Nie zawsze pokrywa się on z odczuciami tożsamościowymi mieszkańców, czemu nie sprzyjają także niewystarczające akcje informacyjne na temat działań jednostek pomocniczych ze strony samorządu na poziomie ogólnomiejskim.

Wielu autorów postuluje wzmocnienie rad dzielnic, wskazując na ich potencjalne możliwości w zakresie partycypacji społecznej (Izdebski 2011). Konkretne rozwiązania proponuje Beata Matyjaszczyk (2011). Należą do nich:

- przyznanie radom jednostek pomocniczych prawa do inicjatywy uchwałodawczej,

- zobowiązanie radnych gminy do zasięgania opinii w sprawach dotyczących dzielnicy lub osiedla u organów tych jednostek,

- ułatwienie przepływu informacji, choćby poprzez umieszczanie informacji o jednostkach pomocniczych w Biuletynie Informacji Publicznej.

Równie pilną kwestią jest także zwiększenie budżetów rad jednostek pomocniczych oraz uproszczenie procedur uruchamiania środków finansowych przeznaczonych na działalność statutową (Raport z realizacji projektu... 2009).

Sytuacja rad dzielnic w polskich miastach nie przedstawia się jednak dramatycznie. Udzielając twierdzącej, choć bardzo złożonej odpowiedzi na pytanie, czy mieszkańcy wielkich miast w Polsce potrzebują rad dzielnic, podkreśla się, że mieszkańcy lepiej znają radnych dzielnicowych czy osiedlowych niż miejskich i bardziej im ufają, częśs ciej przychodzą na konsultacje osiedlowe niż na miejskie i częściej na nich zabierają głos (Lackowska 2014). Nierzadko radni dzielnicowi rekrutują się spośród lokalnych liderów niezależnie działających na rzecz najbliższego otoczenia. Tendencję tę umacnia ekspansja szeroko pojętych ruchów miejskich, które w wyborach samorządowych w 2014 r. wystawiły licznie swoich kandydatów na listach wyborczych. Poza kilkoma spektakularnymi wyjątkami liderzy i liderki ruchów miejskich nie zasiedli jednak masowo w radach miast, część z nich zasiliła właśnie szeregi radnych dzielnicowych. Duże zaufanie, jakim się cieszą, można najpewniej przypisać ich rzeczywistemu zaangażowaniu i szczerej motywacji do działania w służbie lokalnej społeczności. Choć rady jednostek pomocniczych bywają trampoliną do kariery w radach miejskich, zależność ta nie jest jednak regułą (Swianiewicz, Olszowiec 2013).

Kwestię zaufania podnosili w kampanii prowadzonej w mediach społecznościowych kandydaci na radnych dzielnicowych w Gdańsku, na poły żartobliwie wykorzystując fotografię graffiti, jakie pojawiło się w kilku lokalizacjach w mieście (rysunek 1). Mimo że hasło „Zaufaj dobrym radom” de facto nawiązuje do nazwy zespołu hiphopowego 


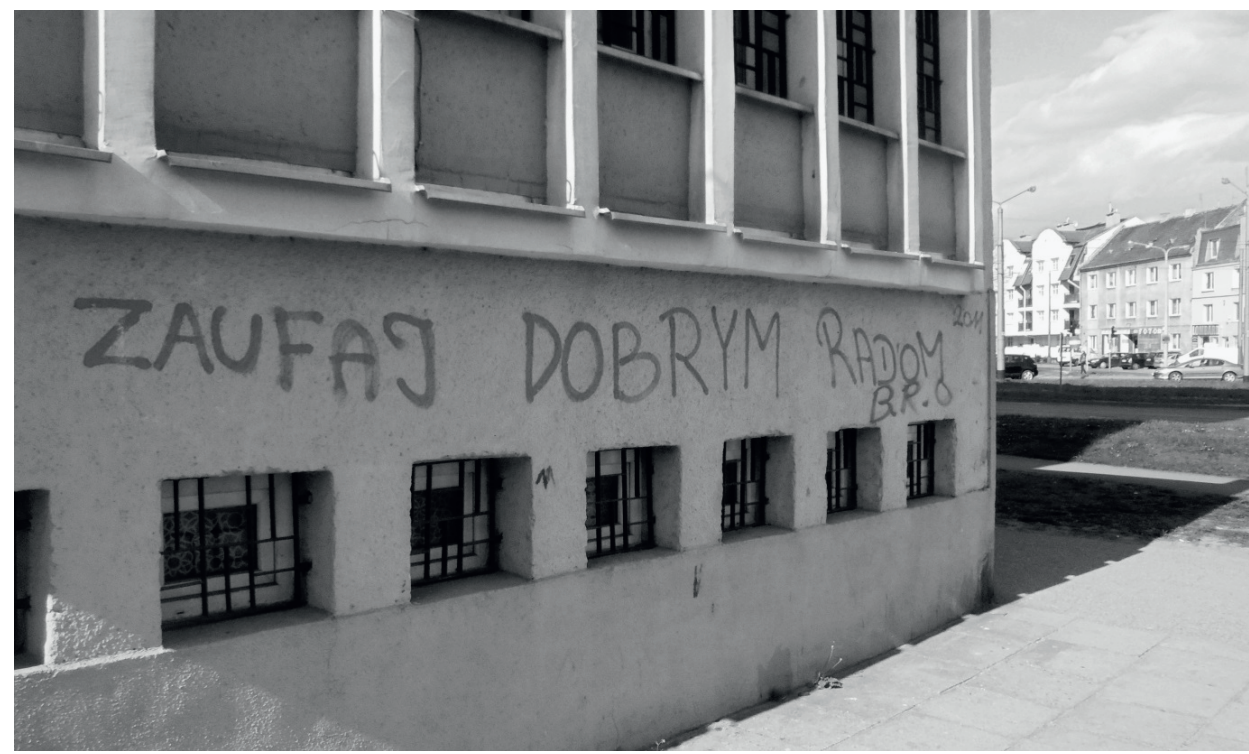

Rys. 1. Napis na murze przy pl. Komorowskiego we Wrzeszczu Dolnym wykorzystywany w kampanii wyborczej do rad dzielnic w $2015 \mathrm{r}$.

Fot. Piotr Dwojacki.

z Radomia, szybko zyskało status mema i było chętnie udostępniane na portalu społecznościowym Facebook w kontekście zbliżających się wyborów.

\section{Procesy kształtowania się rad dzielnic w Gdańsku}

Rady dzielnic zostały powołane w 2002 r. na mocy uchwały nr XLIX/1489/2002 Rady Miasta Gdańska w sprawie określenia organizacji, zasad finansowania oraz zakresu działania jednostek pomocniczych. Z początku tempo powstawania tych jednostek było raczej powolne. W 2009 r. funkcjonowało zaledwie 13 rad dzielnic i osiedli, przy czym w kolejnych trzech jednostkach podjęto nieudaną, ze względu na zbyt niską frekwencję, próbę ich utworzenia, zaś w pozostałych 14 w ogóle nie czyniono starań w tym zakresie. Autorzy Raportu z 2009 r. wymieniają następujące przyczyny takiego stanu rzeczy:

- zbyt wysoki próg frekwencji do utworzenia dzielnicy,

- niedostosowany podział miasta na jednostki pomocnicze,

- mała aktywność społeczna,

- mała wiedza mieszkańców o funkcjonowaniu rad osiedli.

Jednocześnie już wtedy wyniki badań sondażowych dowodziły, iż 2/3 gdańszczan i gdańszczanek uważa, że jednostki pomocnicze gminy są potrzebne.

W 2010 r. władze miasta przeprowadziły reformę, która poskutkowała podziałem największych jednostek pomocniczych. Jednostki te pozostały jednak bardzo zróżni- 
cowane wielkościowo, dlatego też część rad posiadała status rady dzielnicy, część zaś rady osiedla. W 2011 r. odbyły się kolejne wybory i po głosowaniu uzupełniającym na Zaspie-Młyńcu ostatecznie ukonstytuowały się 23 rady osiedli oraz 5 rad dzielnic - tym samym najniższy szczebel samorządowy w Gdańsku liczył 28 jednostek pomocniczych (tabela 1). Ostatecznie jednak w 2014 r. zmieniono status niektórych jednostek pomocniczych i ściśle powiązano rady dzielnicy z obowiązującym podziałem administracyjnym - stąd też obecnie wszystkie dzielnice Gdańska są w stanie powołać własny organ samorządowy.

Tabela 1

Jednostki pomocnicze w Gdańsku w latach 2011-2019 (stan na luty 2017 r.)

\begin{tabular}{|c|c|c|c|}
\hline Kadencja & $\begin{array}{c}\text { Data } \\
\text { wyborów }\end{array}$ & $\begin{array}{c}\text { Liczba } \\
\text { jednostek po- } \\
\text { mocniczych }\end{array}$ & Utworzone jednostki pomocnicze \\
\hline \multirow[t]{2}{*}{ 2011-2015 } & 8.05 .2011 & 27 & $\begin{array}{l}\text { Rady dzielnic: Chełm, Piecki-Migowo, Śródmieście, } \\
\text { Wrzeszcz Dolny, Wrzeszcz Górny } \\
\text { Rady osiedli: Brętowo, Brzeźno, Jasień, Kokoszki, Krako- } \\
\text { wiec-Górki Zachodnie, Letnica, Młyniska, Nowy Port, } \\
\text { Oliwa, Olszynka, Orunia-Św. Wojciech-Lipce, Osowa, Prze- } \\
\text { róbka, Rudniki, Siedlce, VII Dwór, Stogi, Strzyża, Ujeścisko- } \\
\text {-Łostowice, Wyspa Sobieszewska, Wzgórze Mickiewicza, } \\
\text { Żabianka-Wejhera-Jelitkowo-Tysiąclecia }\end{array}$ \\
\hline & 25.09.2011 & 1 & Rada osiedla Zaspa-Młyniec \\
\hline \multirow[t]{4}{*}{$2015-2019$} & 22.03.2015 & 29 & $\begin{array}{l}\text { Rady dzielnic: Aniołki, Brętowo, Brzeźno, Chełm, Jasień, } \\
\text { Kokoszki, Krakowiec-Górki Zachodnie, Letnica, Młyniska, } \\
\text { Nowy Port, Oliwa, Olszynka, Orunia-Św. Wojciech-Lipce, } \\
\text { Osowa, Piecki-Migowo, Przeróbka, Przymorze Małe, Rudni- } \\
\text { ki, Siedlce, Stogi, Strzyża, Śródmieście, Ujeścisko-Łostowice, } \\
\text { Wrzeszcz Dolny, Wrzeszcz Górny, Wyspa Sobieszewska, } \\
\text { Wzgórze Mickiewicza, Zaspa-Młyniec, Żabianka-Wejhera- } \\
\text {-Jelitkowo-Tysiąclecia }\end{array}$ \\
\hline & 28.06 .2015 & 1 & Rada dzielnicy VII Dwór \\
\hline & 5.06 .2016 & 2 & Rady dzielnic: Przymorze Wielkie i Matarnia \\
\hline & 4.12 .2016 & 1 & Rada dzielnicy Suchanino \\
\hline
\end{tabular}

Źródło: Opracowanie własne na podstawie Biuletynu Informacji Publicznej Gdańska, 2015.

Aby powołać radę, frekwencja w wyborach dzielnicowych musi być wyższa niż 5\% przy liczbie kandydatów większej od liczby miejsc w radzie. W większości dzielnic w radzie zasiada 15 osób, jeżeli jednak liczba mieszkańców dzielnicy przekracza 20 tys. mieszkańców, liczba radnych automatycznie zwiększa się do 21 osób. Tak się stało niedawno w dzielnicy Ujeścisko-Łostowice, która ze względu na wzrost podaży nowych mieszkań przekroczyła ten próg w 2013 r. Poza tą dzielnicą w Gdańsku 21 miejsc do obsadzenia w radach dzielnic posiadają Chełm, Piecki-Migowo, Śródmieście oraz Wrzeszcz Górny i Dolny. 
Po wyborach do rad jednostek pomocniczych w marcu 2015 r. zaszły niewielkie zmiany w liczbie rad dzielnic w Gdańsku. Ponownie nie udało się przeprowadzić wyborów we wszystkich dzielnicach Gdańska (na Suchaninie, Przymorzu Wielkim, Matarni, Zaspie-Rozstajach). Bezpośrednio wynikało to z braku inicjatywy mieszkańców, którzy nie złożyli wniosku o powołanie rady dzielnic. Swą szansę natomiast wykorzystały Przymorze Małe oraz Aniołki, gdzie powstały pierwsze rady tych jednostek w historii. Odmiennie niż w 2011 r. nie udało się przeprowadzić wyborów w VII Dworze. Tuż przed wyborami trzej kandydaci zrezygnowali z udziału, wskutek czego nie osiągnięto wymaganego progu liczby startujących osób. Radę udało się jednak powołać w uzupełniających wyborach 28 czerwca 2015 r. Oddolne inicjatywy obywatelskie doprowadziły też do powołania rad w dzielnicach Przymorze Wielkie oraz Matarnia po wyborach 5 czerwca 2016 r., a także na Suchaninie po wyborach 4 grudnia 2016 r. ${ }^{1}$ Tym samym jedyną jednostką pomocniczą bez własnej dzielnicy została Zaspa-Rozstaje.

W Gdańsku rada dzielnicy daje mieszkańcom nie tylko możliwość stworzenia koalicji na rzecz rozwoju lokalnej społeczności, ale także szansę realizacji niewielkich projektów z funduszy miejskich. Urząd Miasta Gdańska uzależnia wysokość transferu środków budżetowych od frekwencji wyborczej w dzielnicy. W 2015 r. jednostki pomocnicze, w których frekwencja wyniosła między 14 a 16\%, otrzymywały dodatkowe fundusze wysokości $25 \%$ transzy podstawowej ( 5 zł na mieszkańca zamiast 4 zł), zaś w przypadku frekwencji wyższej niż $16 \%$ - już $50 \%$ premii ( 6 zł na mieszkańca). W sytuacji ograniczonych środków, jakimi dysponuje rada, może to być istotny instrument motywacyjny.

Mimo że w ciągu ostatnich pięciu lat udało się w Gdańsku częściowo zreformować system funkcjonowania jednostek pomocniczych, istotnym problemem pozostają niewielkie kompetencje rad dzielnic. Dotkliwość ta była szczególnie mocno odczuwalna w relacjach radnych dzielnicowych uczestniczących w debatach na temat przyszłości rad dzielnic, zorganizowanych 18 marca i 15 kwietnia 2015 r. Po pierwszej z nich sformułowane zostały następujące wnioski i rekomendacje, uwzględniające perspektywy trzech stron: radnych miejskich, radnych dzielnicowych oraz mieszkańców. Dotyczyły one przede wszystkim możliwości opiniowania planów zagospodarowania przestrzennego oraz lokalnych inwestycji, a także funduszy na informowanie mieszkańców o tych zmianach (Konopka 2015).

Analizując sytuację w Gdańsku, warto mieć na uwadze, że wśród gdańskich jednostek pomocniczych znajdują się pionierzy rozwiązań partycypacyjnych. Przykładowo budżet partycypacyjny realizowany obecnie na poziomie całego miasta został zapoczątkowany z inicjatywy rady dzielnicy Wrzeszcz Dolny w 2012 r. Z kolei we Wrzeszczu Górnym rada dzielnicy zorganizowała dwie edycje warsztatów planowania partycypacyjnego, a wypracowane tam rozwiązania wprowadzono w życie.

\footnotetext{
${ }^{1}$ Wybory do rady dzielnicy na Suchaninie nastąpiły już po przesłaniu artykułu do redakcji.
} 


\section{Aktywność mieszkanek i mieszkańców Gdańska w wyborach rad dzielnic w 2015 r.}

W 2015 r. gdańszczanki i gdańszczanie wybrali radnych dzielnicowych w 29 z 34 jednostek pomocniczych (rysunek 2). Ogólna frekwencja wyniosła 11,1\% i była wyższa o 0,6 pkt procentowych niż w wyborach w 2011 r. Znaczącą rolę w tym nieco lepszym wyniku mieli mieszkańcy Aniołków, Przymorza Małego, którzy pierwszy raz wybierali swe rady. W obu dzielnicach frekwencja przewyższała średnią dla całego miasta. Większa mobilizacja w trakcie pierwszych wyborów nie była jednak jedyną dostrzegalną determinantą. Szczególnie chętnie swoje rady wybierali mieszkańcy małych dzielnic. Dowodzi tego istotna statystycznie ujemna korelacja pomiędzy liczbą mieszkańców a frekwencją w wyborach do rad dzielnicy $\left(R=-0,625^{* *}\right.$ w 2015 r. oraz $R=-0,657^{* *}$ w 2011 r.). Wyniki w dzielnicach Strzyża oraz Wzgórze Mickiewicza, gdzie głosy oddało odpowiednio 23,3\% i 20,4\% mieszkańców, dobitnie potwierdzają tę zależność.

Dość wysoka frekwencja charakteryzowała dzielnice oddalone od centrum miasta, takie jak: Wyspa Sobieszewska, Kokoszki oraz Osowa. Oddalenie od ośrodka władzy może być czynnikiem mobilizującym do aktywności na rzecz najbliższego otoczenia. Z kolei lokalizacja w centrum może na mieszkańców działać odwrotnie, bowiem najniższą frekwencją cechowało się Śródmieście (6,3\%) oraz dzielnice bardzo dobrze skomunikowane z centrum Gdańska.

Przestrzenny rozkład frekwencji w wyborach do rad dzielnic w 2015 r. był dość zbliżony do frekwencji zanotowanej cztery lata wcześniej. Korelacja obydwu frekwencji wyborczych jest wysoka oraz istotna statystycznie $\left(R=0,747^{* *}\right)$, co nie zmienia jednak faktu, że można odnotować różnice. Największy przyrost frekwencji cechował dzielnice Kokoszki (6,6 pkt procentowych) oraz Młyniska (5,5 pkt procentowych), gdzie trudno doszukać się wspólnych prawidłowości. Wzrost, który nastąpił w niektórych dzielnicach okołośródmiejskich (Letnicy, Nowym Porcie oraz na Wrzeszczu Dolnym), można tłumaczyć efektem podejmowanej rewitalizacji, w której władze dzielnicy zazwyczaj starały się aktywnie uczestniczyć. Frekwencja zmniejszyła się natomiast najbardziej we wschodniej części miasta (z wyłączeniem Wyspy Sobieszewskiej), m.in. w niewielkich dzielnicach przemysłowych, takich jak Krakowiec i Rudniki (spadek o ponad 5 pkt procentowych).

W 2015 r. listy kandydatów do rad dzielnic były mniej oblegane niż cztery lata wcześniej. O ile w poprzedniej kadencji do rad startowało 664 kandydatów, w 2015 r. już tylko 632 pomimo wzrostu liczby wszystkich miejsc do objęcia. Zaledwie 42\% osób zasiadło w radzie ponownie, przy czym najmniej zmieniły się rady Żabianki, Młynisk i Nowego Portu, gdzie zostało ponad 70\% starego składu osobowego. Największe zmiany wystąpiły zaś w Śródmieściu (pozostało jedynie dwóch radnych z poprzedniej kadencji), co może świadczyć zarówno o deficycie rozpoznawalnych liderów społecznych zainteresowanych udziałem w radzie, jak i o silnym podziale wewnętrznym dzielnicy. Dość duże roszady zaszły także w Brętowie, na Jasieniu oraz we Wrzeszczu Dolnym. Radykalne zmiany personalne mogą niekiedy świadczyć o „wypaleniu się” 


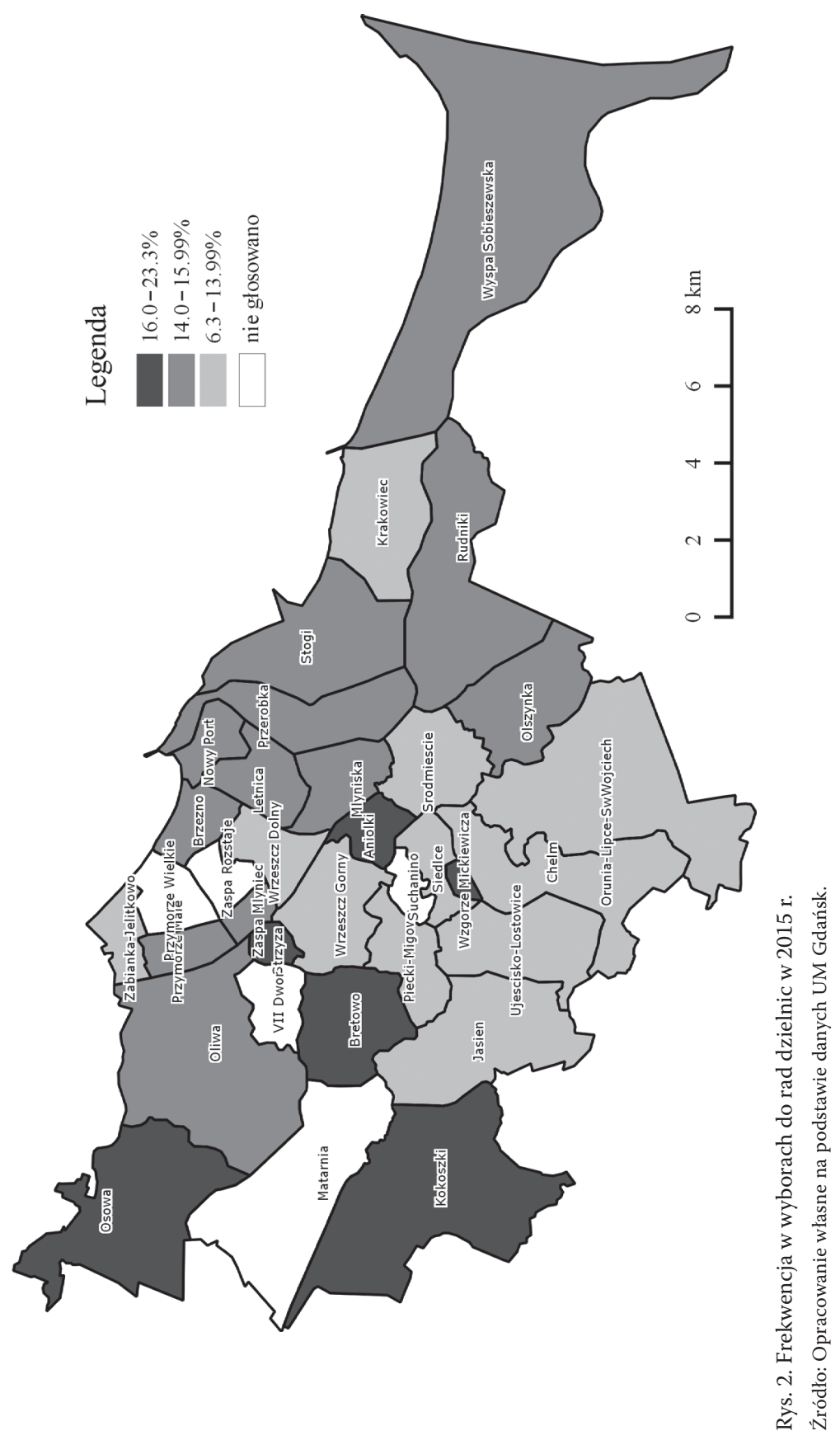


części wcześniejszych radnych, w większości dzielnic konkurencja była bowiem bardzo niewielka. Jedynie na Stogach liczba kandydatów na jedno miejsce w radzie wyniosła dwie osoby, natomiast aż w trzech dzielnicach (Krakowcu, Młyniskach i w Zaspie-Młyniec) balansowano na progu minimalnej liczby startujących (16 osób na 15 miejsc do objęcia).

Przypadek Zaspy-Młyniec jest o tyle ciekawy, że powstała tam rada dzielnicy, której kompetencje na dużych osiedlach blokowych często przejmuje spółdzielnia mieszkaniowa. Spółdzielnie mieszkaniowe ze względu na swą wielkość i strukturę administracyjną na blokowiskach często stanowią „pierwszą pomoc” w załatwianiu codziennych spraw związanych np. ze stanem chodników, zielenią, miejscami parkingowymi (Matczak 2006). Prawdopodobnie dlatego inne dzielnice o podobnej strukturze własnościowej, takie jak Suchanino, Przymorze Wielkie czy Zaspa-Rozstaje, miały trudności z powołaniem rady dzielnicy. Wymienione dzielnice należą także do najstarszych w Gdańsku, stąd mieszkańcy prawdopodobnie z większą rezerwą odnoszą się do zmian i inicjatyw obywatelskich.

Zupełnie inaczej natomiast przedstawiają się zachowania mieszkańców i mieszkanek blokowisk Gdańska w wyborach samorządowych (rysunek 3). Tam frekwencja w 2014 r. była najwyższa, przy czym wystąpił ponadto dość wyraźny podział na liczniej głosującą zachodnią i słabiej głosującą wschodnią część miasta. Pewnym ewenementem jest także Letnica - jedna z najbiedniejszych dzielnic Gdańska, cechująca się m.in. najwyższym poziomem bezrobocia. Frekwencja wyniosła tam zaledwie $21,2 \%$, lecz była tylko o 9 pkt procentowych niższa niż w wyborach do rad dzielnic, w których Letnica przewyższyła średnią dla całego Gdańska. Podobnie jak w przypadku wyborów do rad dzielnic, najwyższą frekwencję w Gdańsku w ostatnich wyborach samorządowych zanotowano na Strzyży oraz Wzgórzu Mickiewicza. Na tym jednak podobieństwa w zakresie uczestnictwa gdańszczan i gdańszczanek w wyborach się kończą.

Frekwencja w wyborach do rad dzielnic nie ma związku z natężeniem wybranych zmiennych społeczno-ekonomicznych (tabela 2). Stopa bezrobocia, liczba przedsiębiorstw i liczba przestępstw w dzielnicy na 10 tys. mieszkańców istotnie korelują pozytywnie bądź negatywnie $\mathrm{z}$ frekwencją w wyborach ogólnomiejskich, ale już nie w dzielnicowych.

Co więcej, aktywność w zakresie składania projektów do budżetu obywatelskiego nie ma wpływu na frekwencję w wyborach dzielnicowych (rysunek 4). Można zaryzykować nawet hipotezę, że to m.in. brak możliwości przeforsowania swoich projektów wpłynął na mobilizację mieszkańców w Aniołkach i Przymorzu Małym do utworzenia własnej rady. Duże dzielnice realizowały większą liczbę projektów niż dzielnice mniejsze, ale też lepiej mobilizowały społeczność wokół przedsięwzięć dedykowanych partykularnym interesom wąskiej grupy (np. rodzice postulujący budowę boiska szkolnego przy określonej szkole), stąd też występują pewne obiekcje co do zasadności stosowania tej miary w analizie.

Bazując na zachowaniu mieszkańców Gdańska w wyborach ogólnomiejskich i dzielnicowych, można pokusić się o sformułowanie typologii, jako że obydwie zmienne nie 


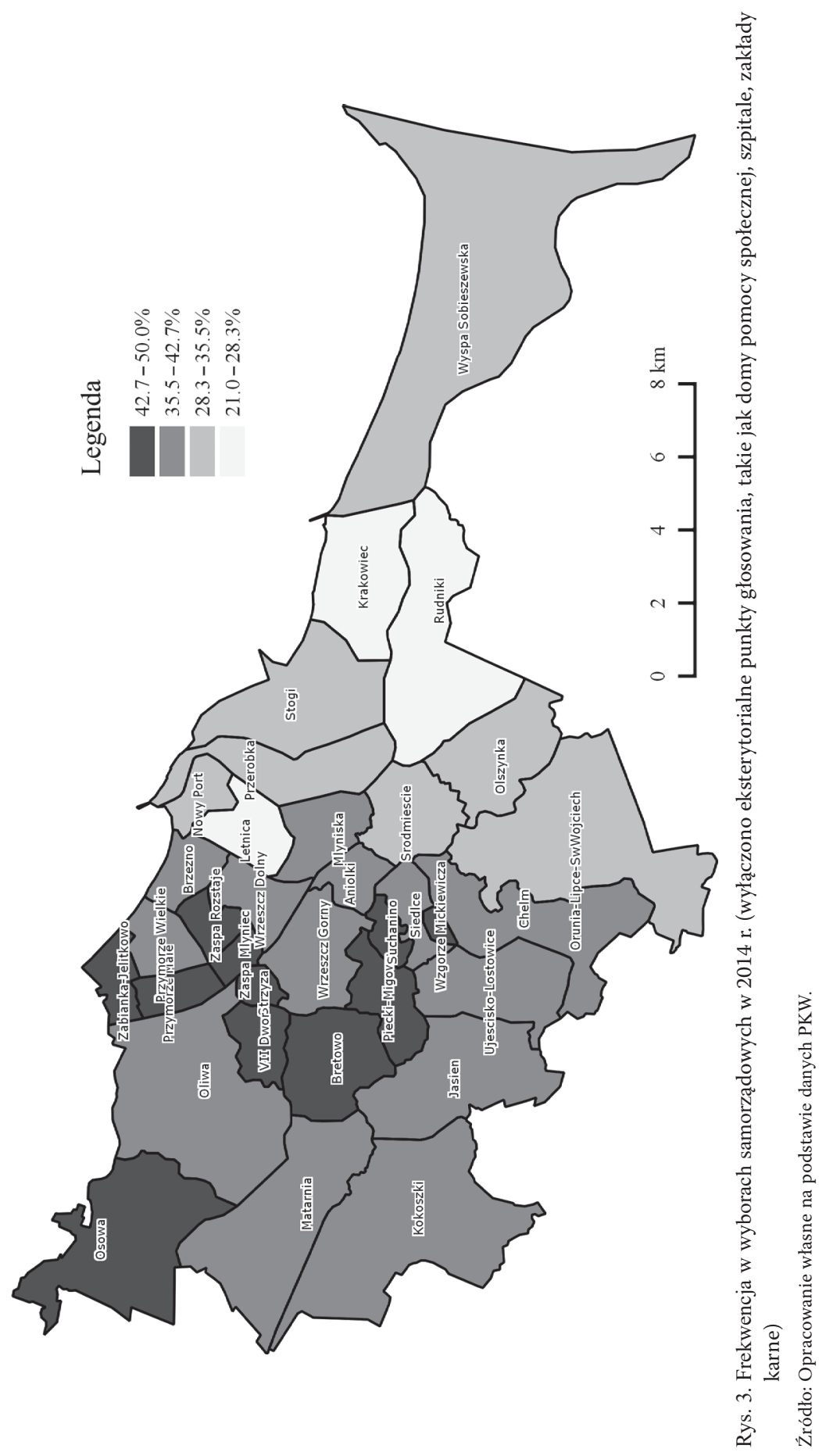


są ze sobą skorelowane. Teoria kapitału społecznego często wykorzystuje frekwencję wyborczą jako jedną z miar tego zjawiska (Putnam 2001). Pamiętając o niedoskonałości wskaźnika, zaproponowano operacjonalizację tej teorii.

Tabela 2

Powiązanie frekwencji w wyborach dzielnicowych i ogólnomiejskich ze zmiennymi społeczno-ekonomicznymi

\begin{tabular}{|l|c|c|}
\hline \multicolumn{1}{|c|}{ Zmienna niezależna } & $\begin{array}{c}\text { Frekwencja w wybo- } \\
\text { rach do rad dzielnic } \\
(2015)\end{array}$ & $\begin{array}{c}\text { Frekwencja w wy- } \\
\text { borach ogólnomiej- } \\
\text { skich (2014) }\end{array}$ \\
\hline Liczba mieszkańców dzielnicy & $-0,625^{* * *}$ & 0,246 \\
\hline Frekwencja w wyborach do rad dzielnic (2011) & $0,747^{* * *}$ & $-0,104$ \\
\hline $\begin{array}{l}\text { Udział osób bezrobotnych w stosunku do osób w wieku } \\
\text { produkcyjnym w dzielnicach }\end{array}$ & $-0,127$ & $0,893^{* * *}$ \\
\hline Liczba przedsiębiorstw na 10 tys. mieszkańców dzielnicy & 0,074 & $-0,474^{* * *}$ \\
\hline Liczba przestępstw na 10 tys. mieszkańców dzielnicy & $-0,186$ & $-0,714^{* * *}$ \\
\hline $\begin{array}{l}\text { Udział mieszkań komunalnych w stosunku do liczby } \\
\text { mieszkańców dzielnicy }\end{array}$ & $-0,049$ & $-0,830^{* * *}$ \\
\hline $\begin{array}{l}\text { Udział osób korzystających z dodatku mieszkaniowego } \\
\text { na 10 tys. mieszkańców dzielnicy }\end{array}$ & 0,302 & $-0,307$ \\
\hline $\begin{array}{l}\text { Liczba projektów realizowanych w ramach budżetu } \\
\text { obywatelskiego }\end{array}$ & $-0,309$ & 0,080 \\
\hline
\end{tabular}

* korelacja istotna statystycznie na poziomie 0,05 ; ** korelacja istotna statystycznie na poziomie 0,01 .

Źródło: Opracowanie własne na podstawie danych PKW oraz UM Gdańsk.

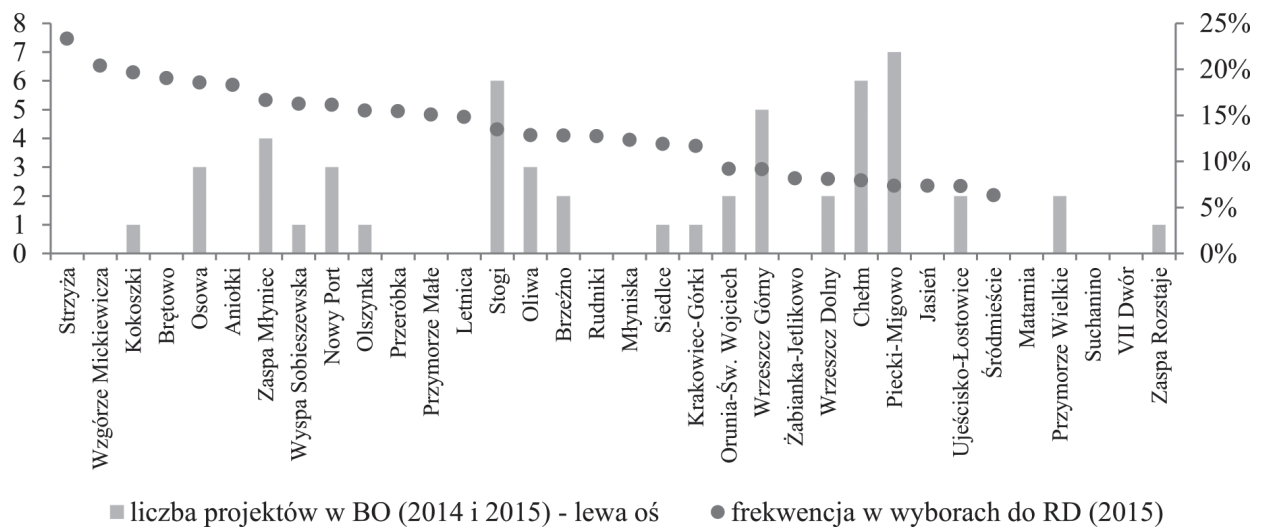

Rys. 4. Frekwencja w wyborach do rad dzielnic w 2015 r. a liczba projektów złożonych do Budżetu Obywatelskiego w 2014 i 2015 r. (dotyczy projektów tzw. dzielnicowych, umiejscowionych konkretnie w danej dzielnicy, w odróżnieniu od projektów ogólnomiejskich)

Źródło: Opracowanie własne na podstawie danych PKW oraz UM Gdańsk. 
Frekwencja w wyborach samorządowych w dużym mieście może dostarczyć informacji o skali pomostowego kapitału społecznego, czyli otwartości i gotowości do współpracy na rzecz ogólnomiejskiego dobra wspólnego. Mieszkańcy muszą bowiem podjąć decyzję dotyczącą całego miasta i wyjść poza swe najbliższe otoczenie, inaczej niż w przypadku wyborów dzielnicowych, przez które raczej podkreślają skalę związków z poziomem sąsiedzkim². Zgodnie z tym podziałem można podzielić miasto na cztery klasy o różnym natężeniu obu rodzajów kapitału społecznego (rysunek 5).

Za punkt odniesienia, według którego przyporządkowano dzielnicę do danej klasy, przyjęto odległość od średniego wyniku dla Gdańska w wyborach samorządowych i dzielnicowych. W efekcie można mówić o wyraźnym geograficznym klastrowaniu się dzielnic miasta na stosunkowo spójne topologicznie obszary. Dzielnice zachodnie Gdańska charakteryzuje wysoki poziom frekwencji zarówno w wyborach do rad dzielnic, jak i w wyborach ogólnomiejskich. W wyborach ogólnomiejskich mieszkańcy blokowisk uczestniczyli liczniej, natomiast deficytem obydwu rodzajów kapitału społecznego charakteryzowały się dzielnice śródmiejskie i okołośródmiejskie. Wyróżnić można także odrębne skupisko we wschodniej części miasta, gdzie udział w wyborach dzielnicowych jest wyższy niż średnia w stosunku do wyborów ogólnomiejskich prawdopodobnie w biedniejszej części Gdańska dominuje „wiążący” kapitał społeczny, który jest też związany z koncentracją niewielkiej liczby mieszkańców na stosunkowo słabo zabudowanym terenie (np. Letnica). Prezentowana typologia nie uwzględnia dzielnic, w których nie powstały rady, natomiast uwzględnia te jednostki, w których rady powoływano po raz pierwszy - stąd np. tak nietypowy wynik Aniołków.

Na podstawie niniejszej typologii wybrano do pogłębionej analizy dwie najbardziej skrajne dzielnice, charakteryzujące się najwyższym i najniższym zasobem obydwu kapitałów - Strzyżę oraz Śródmieście.

\section{Uwarunkowania aktywności w wyborach do rad dzielnic a inne formy zaangażowania obywatelskiego na przykładzie Strzyży oraz Śródmieścia}

Biorąc pod uwagę kompetencje i potrzeby mieszkańców, zakres działalności radnych w Strzyży i Śródmieściu był dość podobny. Radni dzielnicy zajmowali się przede wszystkim sprawami związanymi z transportem, zielenią miejską, rekreacją oraz gospodarką odpadami na terenie dzielnic. W Śródmieściu istotnym tematem było wspomaganie aktywności seniorów oraz lokalnych stowarzyszeń. Obydwie rady znacząco różniły się jednak postawą proaktywną w stosunku do dzielnicy, która była wyższa w jednostce cechującej się ponad trzykrotnie wyższą frekwencją.

\footnotetext{
${ }^{2}$ Poziom sąsiedzki odzwierciedla z kolei kapitał społeczny wiążący, rozumiany jako zakorzenienie w lokalnej społeczności.
} 


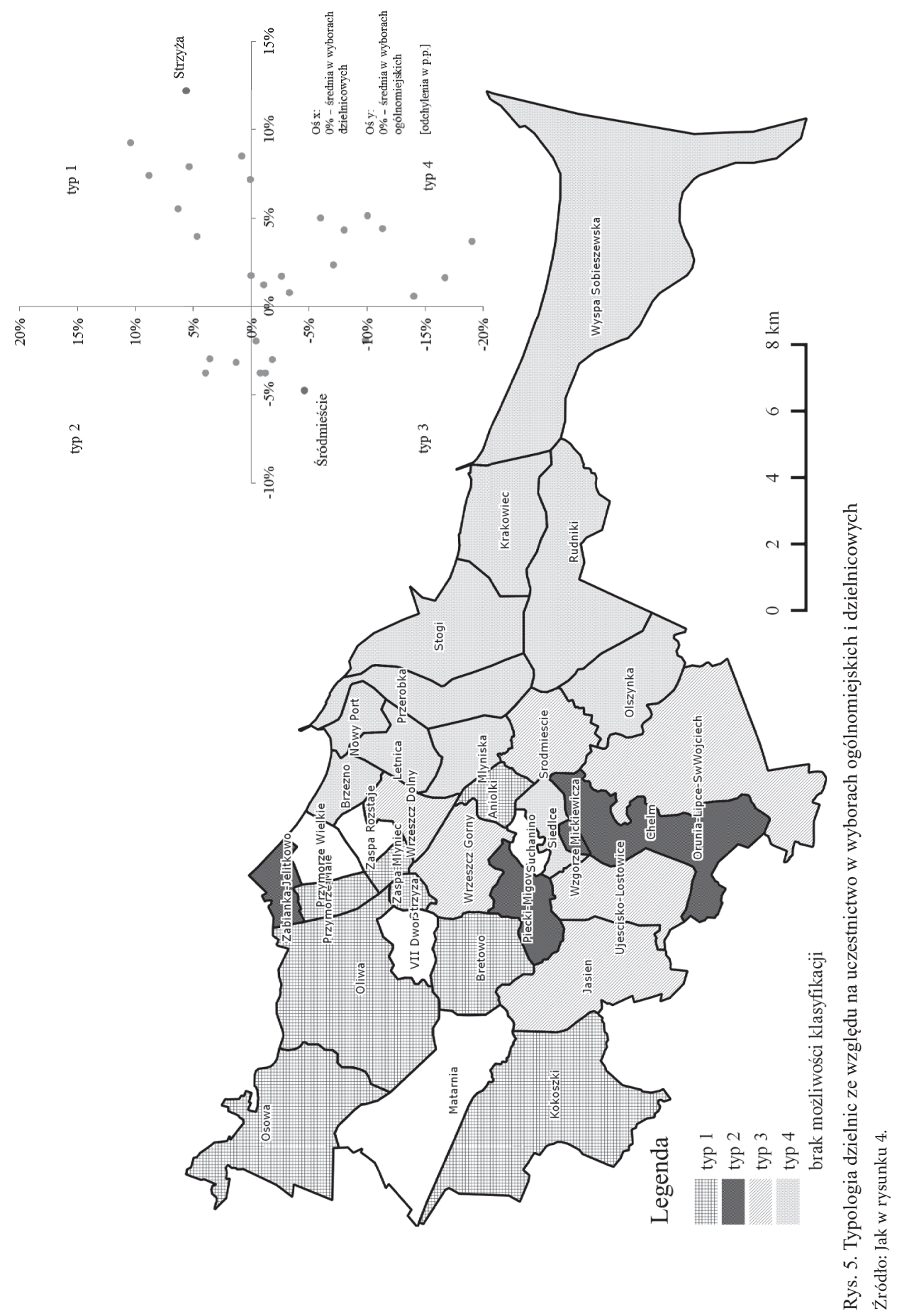


Czynnikiem sprawczym powstania jednostek pomocniczych była parafia (Strzyża) oraz stowarzyszenie sympatyków dzielnicy (Śródmieście). Rola oddolnych stowarzyszeń jest szczególnie interesująca. Pozytywnie ocenianym przykładem organizacji komplementarnej przez mieszkańców Strzyży był klub przyjaciół dzielnicy, który ze względu na posiadanie osobowości prawnej często wspomaga radę w pozyskiwaniu funduszy. Istotnym uzupełnieniem tej koalicji na rzecz dzielnicy jest też jedyna w dzielnicy parafia, dzięki której informacje o działalności rady trafiają do mieszkańców nieposiadających dostępu do Internetu. Zdaniem radnego dzielnicy parafia była „naturalnym integratorem społeczności jeszcze za czasów komunizmu, a także przemian ustrojowych", choć oddolnej aktywności musi sprzyjać przede wszystkim niewielka powierzchnia i liczba ludności.

Rola oddolnego stowarzyszenia w Śródmieściu została natomiast przez jednego $\mathrm{z}$ radnych oceniona ambiwalentnie. Mimo że uznawał niebagatelną rolę stowarzyszenia przy powołaniu rady dzielnicy, to jednak twierdził, iż proces „zawłaszczania” rady przez jego członków nie powinien mieć miejsca w takiej skali.

Radni zgadzali się, że niewielka wymiana ludności prowadzi do silniejszego związku z otoczeniem. Na Strzyży ostatnia duża imigracja nastąpiła w latach 50. ubiegłego wieku, można więc stwierdzić, że wspólnie zamieszkiwały tam trzy pokolenia. Natomiast w Śródmieściu wymiana ludności następuje szybciej, ponadto dzielnicę cechują wysokie ceny nieruchomości, stąd też ludzie raczej rzadko decydują się na kupno mieszkań w tej okolicy, często zaś na wynajem - co powoduje słabszy związek z dzielnicą.

Kolejnym istotnym czynnikiem wpływającym na zaangażowanie obywatelskie jest także podział administracyjny w konfrontacji z zasięgiem codziennych usług. Mieszkańcy nie są świadomi dokładnego przebiegu granic dzielnic i swe codzienne i cotygodniowe aktywności kierują w stronę najbliższej szkoły i parafii, często położonej już na obszarze innej jednostki pomocniczej. Zdaniem radnego dzielnicy Strzyża przykład ten może np. dotyczyć nowego osiedla Garnizon, które administracyjnie należy do Wrzeszcza Górnego, lecz posiada dużo silniejsze związki funkcjonalne ze Strzyżą.

Podobnie jak al. Grunwaldzka i al. Żołnierzy Wyklętych mogą stanowić bariery dla mieszkańców tamtej części Gdańska Wrzeszcza, problem „rozbicia dzielnicowego” dotyczy także Śródmieścia - dużej, rozczłonkowanej arteriami komunikacyjnymi dzielnicy, która mogłaby zostać podzielona na szereg mniejszych, bardziej spójnych wewnętrznie jednostek (np. Dolne Miasto, Główne Miasto, Biskupia Górka). Istotny wpływ na aktywność obywatelską prawdopodobnie ma także sama procedura wyborów do rad dzielnicy. Mniejsza o połowę liczba punktów do głosowania sprawia, że wyborcy nie zawsze orientują się, gdzie dokładnie powinni się udać. Ponadto konieczność opłacania kampanii informacyjnych z własnych środków, a także relatywnie słaba promocja wyborów ze strony miasta wpływa negatywnie na wysokość frekwencji. Należy także nadmienić, że słaba promocja rad dzielnic (nie tylko na etapie kampanii, ale także działalności) powoduje nieświadomość mieszkańców w zakresie samego istnienia rady dzielnicy. Trudno bez sukcesów na tym polu zmobilizować lokalną społeczność. W tym aspekcie bardzo istotną rolę odgrywa proaktywność oraz sprawna organizacja działania 
rady. Wychodząc proaktywnie w stronę partnerstw z organizacjami pozarządowymi, deweloperem oraz np. miejską spółką ciepłowniczą, rada dzielnicy jest w stanie przeprowadzić więcej inicjatyw, niż pozwala jej na to ograniczony budżet.

\section{Wnioski}

Główny wniosek wypływający z badania jednostek pomocniczych w Gdańsku wskazuje na uzależnienie aktywności lokalnej od wielkości jednostki pomocniczej oraz skali wymiany społecznej, która w niej zachodzi. Wyjątkiem są wielkie osiedla mieszkaniowe, w których zarządy spółdzielni przejmują rolę rad dzielnic. Nie stwierdzono natomiast związku z uczestnictwem w wyborach ogólnomiejskich ani lokalną sytuacją społeczno-gospodarczą. Czynnik „zasiedzenia” świadczący o wiążącym kapitale społecznym wydaje się silniej wyjaśniać frekwencję w wyborach do rad dzielnic niż na przykład status materialny, pozytywnie korelujący z frekwencją w wyborach do rady miasta. Można też wysunąć ostrożną hipotezę, że nowi mieszkańcy dzielnic peryferyjnych, notujących dynamiczny przyrost mieszkańców, wcale nie są bierni w działaniach na rzecz najbliższego otoczenia.

Gdański model budżetu partycypacyjnego premiuje większe dzielnice, w których zaangażowanie obywatelskie jest słabsze, nie spełnia więc na razie założonej funkcji. Większe znaczenie dla efektywnego działania rad dzielnic mają ich relacje z lokalnymi organizacjami społecznymi. Przykład Strzyży obrazuje, jak silna rada umiejętnie pozyskuje środki finansowe na projekty dzięki licznym partnerstwom, podczas gdy radni śródmiejscy wykazują mniej proaktywną postawę, raczej udzielając poparcia niż wychodząc z inicjatywą.

Paradoksalnie, mimo coraz większego zaangażowania mieszkańców, dotychczasowi radni dzielnicowi są coraz mniej skłonni do kandydowania w wyborach. Jedynie $42 \%$ radnych ponownie wybrano na drugą kadencję, co przy niewielkiej konkurencji wskazuje, że duża część dotychczasowych działaczy zrezygnowała ze startu w wyborach. Ten słaby wynik może wynikać z niewielkich kompetencji jednostek pomocniczych, co sprawia, że efekty działań rad dzielnic mogą być niewspółmierne do nakładów pracy i energii.

Z terytorialnego punktu widzenia istotnym wnioskiem jest rozbieżność codziennych zachowań przestrzennych mieszkańców z podziałem administracyjnym miasta, co również może wpływać negatywnie na frekwencję. Ponadto polityka budowania dużych arterii komunikacyjnych przecinających miasto powoduje powstawanie sztucznych barier, będących nowymi krawędziami miejskimi, co skutkuje dezintegracją społeczności lokalnych w obrębie dotychczasowych dzielnic.

\section{Bibliografia}

Basaj M., 2013, Instrumenty partycypacji społecznej w teorii i praktyce zintegrowanego zarzadzania miastem, "Acta Universitatis Nicolai Copernici. Zarządzanie XL” z. 413. 
Biuletyn Informacji Publicznej Gdańska, 2015, http://www.gdansk.pl/bip/ (dostęp 9 czerwca 2016).

Filar P., Kubicki P., 2012, Lepsze, zrównoważone miasto. Podsumowanie, [w:] Miasto w działaniu. Zrównoważony rozwój z perspektywy oddolnej, red. P. Filar, P. Kubicki, Instytut Obywatelski, Warszawa.

Fischer S., Pleines H., 2014, Civil society in Central and Eastern Europe, Ibidem Press, Stuttgart.

Harvey D., 2012, Bunt miast. Prawo do miasta i miejska rewolucja, przeł. A. Kowalczyk et al., Fundacja Nowej Kultury Bęc Zmiana, Warszawa.

Izdebski H., 2011, Jednostki pomocnicze gminy - pomiędzy organami gminy a obywatelami jako podmiotem wtadzy lokalnej, „Samorząd Terytorialny” nr 12.

Jaśkowiec D., 2012, Wpływ rad dzielnic na politykę samorzadowa władz Krakowa - analiza na wybranych przykładach, „Państwo i Społeczeństwo” nr 3.

Kalisiak-Mędelska M., 2012, Funkcjonowanie jednostek pomocniczych (osiedli) w Lodzi. Analiza wyników badania pilotażowego, „Prace Naukowe Uniwersytetu Ekonomicznego we Wrocławiu” nr 243.

Konopka A., 2015, Co dalej z radami dzielnic w Gdańsku?, Dziennik Opinii, 10 kwietnia 2015, http:// www.krytykapolityczna.pl/kluby-kp/trojmiasto/20150410/co-dalej-z-radami-dzielnic-w-gdansku (dostęp 9 czerwca 2016).

Lackowska M., 2014, Czy mieszkańcy wielkich miast potrzebuja jednostek pomocniczych?, „Samorząd Terytorialny" nr 1-2.

Matczak P., 2006, Czynniki podejmowania działalności w samorzadach pomocniczych. Przykłady Poznania $i$ Kalisza, [w:] Czy społeczny bezruch?, red. M. Nowak, M. Nowosielski, Instytut Zachodni, Poznań.

Matczak P., 2010, Rady osiedli: czemu stuża, kto za nimi stoi?, Pracownia Badań i Innowacji Społecznych Stocznia, Warszawa.

Matyjaszczyk B., 2011, Jednostki pomocnicze gminy - analiza uwarunkowań prawnych, Pracownia Badań i Innowacji Społecznych Stocznia, Warszawa.

Piechota G., 2013, Jednostki pomocnicze w strukturach zarzadzania polska gmina (analiza funkcjonowania jednostek pomocniczych w ślaskich miastach na prawach powiatu), „Samorząd Terytorialny” nr 3.

Putnam R., 2001, Social capital: Measurement and consequences, "Canadian Journal of Policy Research" No. 2(1).

Raport z realizacji projektu „Nic o nas bez nas” - kształtowanie roli i zadań jednostek pomocniczych gminy, 2009, Regionalne Centrum Informacji i Wspomagania Organizacji Pozarządowych, Gdańsk.

Swianiewicz P., Krukowska J., Lackowska M., Kurniewicz A., 2013, Błędne rondo marginalizacji? Jednostki pomocnicze samorzadu w zarzadzaniu dużymi miastami, Dom Wydawniczy Elipsa, Warszawa.

Swianiewicz P., Olszowiec K., 2013, Samorzad jednostek pomocniczych wielkich miast jako ścieżka kariery politycznej, „Studia Regionalne i Lokalne” nr 4(54). 